upon Islamic thinkers. Chapter 13 consists largely of an extended critique of Thomas Kuhn's portrayal of the birth of modern science from Copernicus until Newton, with Bala taking him to task for adhering to dogmatic Eurocentrism. The significance of this chapter is difficult to exaggerate. Bala's independence of mind is demonstrated in his discussion of the alchemical and occult roots of the heliocentric vision entertained by Copernicus and motivating Newton, which Bala traces to the impact of Hermetic philosophy rooted in ancient Egyptian solar cosmology (pp. 152-7, 162, 173-4). He rightly dismisses T. Kuhn's identification of such ultimately Egyptian elements as merely neoplatonic (i.e. Greek), this being an instance of Eurocentric aggrandizement.

Bala provides an informed historical critique and persuasive intellectual synthesis which attains a sustained level of consistent plausibility. His work will surprise and intrigue many, deflate the self-assured vain confidence of others, and mightily enlighten those thirsting for a global perspective on our human search for a more adequate model of the universe. What is at stake in these pages is nothing less than the urgent need to forge new 'corridors of communication' between civilisations and polities - beyond the trite outmoded notions of competition or clash, and toward conversations yielding reciprocal cooperation and mutual convergence. Arun Bala is to be congratulated for the vigour and originality of his thoughts and for the energy and conviction which dish them out to nourish his readers.

\title{
James A. Roumasset, Kimberly M. Burnett and Arsenio Balisacan (eds), Sustainability Science for Watershed Landscapes
}

(Singapore: ISEAS, 2010), 346 pp. ISBN: 9789814279963 . US\$14.90

\section{Eric Winkel International Institute of Advanced Islamic Studies (IAIS) Malaysia}

The word 'sustainability' has blossomed into so many ideas (some count 500) that it risks losing any scientific value. The authors of Sustainability Science for Watershed Landscapes take a concept of positive sustainability that posits sustainable growth as neither an objective nor a constraint. Their most important contribution is their effort "to embrace policy sciences" (p. 3, Ravago et al.).

We seem to have in the field research and studies that are scientific, and writing that is political, activist, and advocatory. Even within this volume, it is not obvious that the two directions can merge or even speak to each other. On the political side, we have a particular analysis of a problem:

'greedy growth,' the proliferation of government entities, projects and regulatory policies to transfer rents from taxpayers to the 'iron triangle' of politicians, bureaucrats, and special interests. (Ravago et al., p. 16) 
The authors describe this iron triangle:

Facilitation via cozy arrangements between the government and industrial-financial conglomerates can lead to erosion of fiduciary accountability as in the East-Asian financial crisis of 1997 and the US-led world recession of 2007-2009. (Ravago et al., p. 17)

With this iron triangle, money speaks and corporations get their way:

[P]olitically influential entrepreneurs are able to obtain exemptions or easy passage through the barriers. For example, even though the poultry lobby has managed to use the WTO apparatus to protect themselves from importation of low market-valued chicken parts, McDonalds has succeeded in exempting themselves. Similarly, Coca-Cola and other large companies have managed to secure low-cost sugar, even as potential small-scale candy makers and canned fruit manufacturers are unable to access the same benefit. While Monsanto and Cargill may be able to accelerate the Bureau of Plant and Industry quarantine procedures and other restrictions on importing seeds, farmers who want to experiment with new varieties would face great difficulty in doing so. (Ravago et al., p. 23)

What is unclear is how 'science' is going to break the iron triangle. What is worse, we know how 'science' can get implicated into the iron triangle. A partial answer is policy science, and that means finding ways to get the science into policy. And one way is to work for a 'virtuous circle' with transparency and accountability. "The third condition for the endurance of the virtuous circle is for transparency and accountability to become more than buzz words. Transparency includes information systems that reveal what the government is doing, what the economic consequences are, what groups enjoy the benefits, and who bears the costs" (Ravago et al., p. 29). Governments that have declared themselves interested in transparency could then be approached this way.

The apparent split between "science" and "politics" is seen by the public. They do not see governments working from science, and so they assume failures are failures of science, not politics (such as the iron triangle). The authors describe it this way:

Because of these so-called 'boundaries' between scientists and decision makers, knowledge and action are de-coupled because of failures to integrate, communicate, and translate information effectively into action. As a result, knowledge systems are used ineffectively. This has caused crop yields, fishery stocks, and water levels in aquifers to decline. Because of such failures, scientific information is unjustly viewed by the public as lacking in 'salience, credibility, and legitimacy'. (Kido et al., p. 128)

In a way mirroring the apparent split, other contributions to this volume are highly technical, local studies. How they fit into the big picture - or into the iron triangle picture - is not clear. However, the beginnings of a real solution may be emerging. "A central challenge of sustainability science is how to make research practical and 
action-based as well as advancing the frontiers of scientific knowledge" (Burnett et al., p. 341). These technical and local studies explore the positive ways information can be used by the actors involved. Knowing differences in water content of soil under rubber, tea, secondary forest and grassland sites, for example (GuardiolaClaramonte et al., p. 245) is important for policy. Understanding how feral pigs lead to mosquito proliferation (by consuming the inner cores of native ferns [Bruland et al., p. 256]) is important for policy.

When governments are able to access solid science and the 'knowledge systems' of scientists, they are able to make policies that are beneficial. There is still a political dimension for activists, but certainly there is a need for policy-relevant science. This volume is an important start toward the integration of science and policy.

\section{Jonas Adelin Jørgensen, Jesus Imandars and Christ Bhaktas: Two Case Studies of Interreligious Hermeneutics and Identity in Global Christianity. Studies in the Intercultural History of Christianity 146} (Frankfurt am Main: Peter Lang, 2008). xii+481 pp. ISBN: 9783631584866. US\$107.95

\section{Mika Vähäkangas Centre for Theology and Religion, Lund University}

The end of colonialism, the previously unparalleled level of religious plurality due to both migration and internal diversification of various societies, and lastly the shift of the centre of gravity to the global South in terms of the membership of Christian churches are changes with which Western academic Christian theology has to come to grips with. The high tide of colonialism, and its theological equivalent ethnocentric religious arrogance - was followed by the end of colonial era, reflected also in theology. When one combined the suddenly grown religious pluralism in the West and the remorse for the colonial past an outcome was a number of liberal (or, at times, seemingly liberal) pluralistic or relativistic theologies of religion. That could be called 'post-colonial' in the sense of being epi-colonial.

To reach a real post-colonial stage in theologies of religions, i.e. leaving colonial heritage behind, a new generation seems to be needed - born after the colonial era, and to whom religious plurality is a self-evident fact. Jonas Adelin Jørgensen, a Copenhagen missiologist and systematic theologian, belongs to that generation. He analyses the faith and the practice of two types of believers on the border-zone between Christianity and other religions: Jesus imandars of Dhaka, Bangladesh and Christ bhaktas of Chennai, India. They both confess Jesus as their focus of faith while clinging to their identities as Muslims and Hindus. 